\title{
Es real porque es imaginado Entrevista a Armando Silva
}

\section{POR PAULA VERA}

paulavera.arg@gmail.com - Consejo Nacional de Investigaciones Científicas y Técnicas (CONICET). Centro REDESUniversidad Nacional de Quilmes (UNQ). Centro de Estudios Culturales Urbanos (CECUR), Universidad Nacional de Rosario (UNR)

El Dr. Armando Silva es una figura clave en los estudios sobre la ciudad, la estética y las emociones ciudadanas. A partir de estos objetos ha desplegado su teoría de los imaginarios urbanos, junto a una metodología de investigación que ha incentivado y contribuido a consolidar un campo de estudios específico desde una mirada latinoamericana.

Paula Vera: En su libro Imaginarios, el asombro social usted recupera y actualiza el concepto de imaginarios urbanos que ha venido trabajando durante más de veinte años. Nos gustaría saber cómo surge el concepto, cuál fue su devenir y cómo define hoy los imaginarios urbanos.

ArmandoSilva:Losimaginarios están hechos de estética. Alserasí, cambia la perspectiva, pues ya no se trata solo del registro de una inscripción psíquica -en la tradición de Lacan, Metz y Castoriadis, que abrieron este campo-, sino de llevar el imaginario a una convivencia social en la que se puede estar en estado imaginario, si domina una función estética frente un determinado acontecimiento. O sea, el imaginario sí puede ser dominante y llevarnos a un mundo real, pero imaginado: es real porque es imaginado. O puede que lo imaginado sea pobre o empobrecido, y así domina lo referencial y cierto - por comprobable - sobre lo imaginado. Eso hizo que propusiera en el libro que usted menciona un modelo tríadico, adonde llevo esas posibles opciones de percepción social de la realidad. Lo que sigue intacto desde que publiqué mi primer libro con el título delos Imaginarios urbanos es quela base de reflexión es el fantasma urbano, o sea, si se da cuenta nunca hablé de "imaginario de ciudad", sino urbanos. En otras palabras: el fantasma no es un ser físico, sino una figura psíquica que afecta la percepción de la ciudad (urbanismos ciudadanos); por tanto, como dije desde aquellos años iniciales, lo imaginado es el filtro desde donde vemos la ciudad real. La realidad no es lo real, sino el fantasma de lo real.

P.V. ¿Qué es lo asombroso de o en los imaginarios sociales?

A.S. Si entendemos una tradición estética desde Kant, pero revisada como 
epistemología por E. Garroni -donde bien sostiene que la estética es una manera de ver el mundo no equiparable al sentido lingual, "y por tanto existe entonces una experiencia estética o una cualidad de característica estética en ciertas experiencias" - , se nos permite entonces una salida al sujeto vivencial que admite opciones: histórica, cultural y otras. La experiencia estética será histórica y no le pertenece a una sociedad o cultura específica. Y si seguimos con el formalismo ruso y el checo, en especial en la obra de Jan Mukarovsky, se puede ver, con este último, que la estética se mundaniza, no queda en la abstracción kantiana de trascedente; quelo es, pero también es el efecto de una función sobrela vida social. Vendrán muchos otros autores (Benjamin, Derrida, Nancy, entre otros) que puntualizan la estética como una valoración delas artes, y poco a poco de la vida social. Como lo hace Ranciere llenando de tales propiedades al espectador emancipado (desde la estética, digo yo).

Si domina una función estética, entonces estamos en alto grado de dominio imaginario, y este es el origen del asombro. Estar asombrado es estar en estado imaginado, dominado por un imaginario. La clave misma está en el origen del término. Asombro viene de sombra, proyección oscura de la imagen de un cuerpo opaco que intercepta rayos de luz, dice el diccionario; pero se le agrega la "a" <a- asombrar> propio de nuestra lengua para formar verbos. Asombro entonces significa sorpresa, admiración, pasmo, desconcierto sobre algo que merecía certeza. Uno se puede asombrar por el aparecimiento de un caballo en una calle urbana (foto 1). También uno puede asustarse por la aparición de una sombra (foto 2) en Guayaquil, foto que tomé desde el río Guayas y que da la impresión de que es una estatua real convertida en fantasma; paso a paso desde mi barcaza en movimiento daba la impresión de que se estaba metiendo en un apartamento. Así operan estos engaños visuales y cognitivos en la vida social.

Figura 1: Caballo en calle urbana

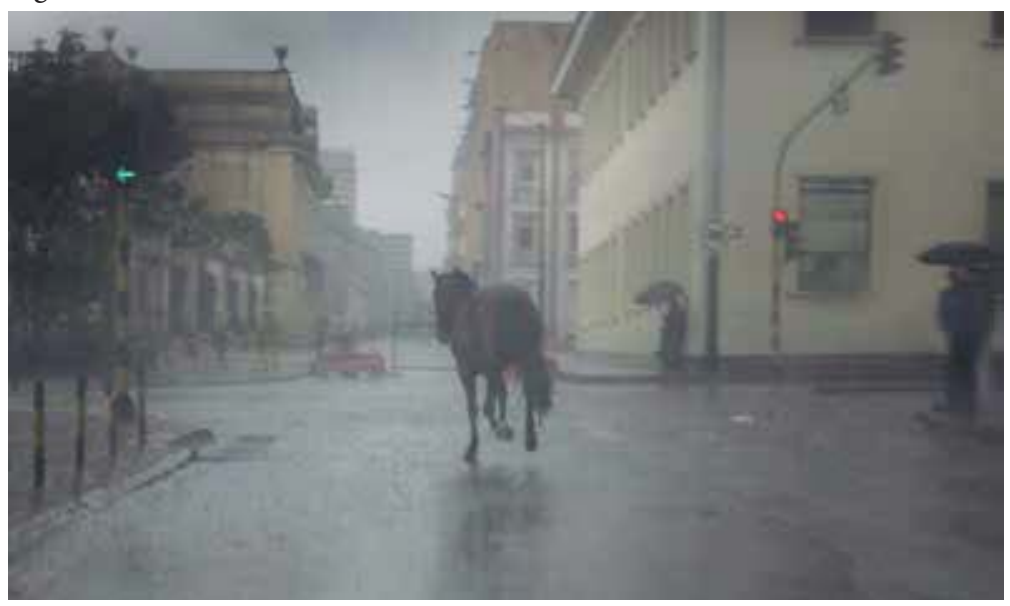


Figura 2: Guayaquil.

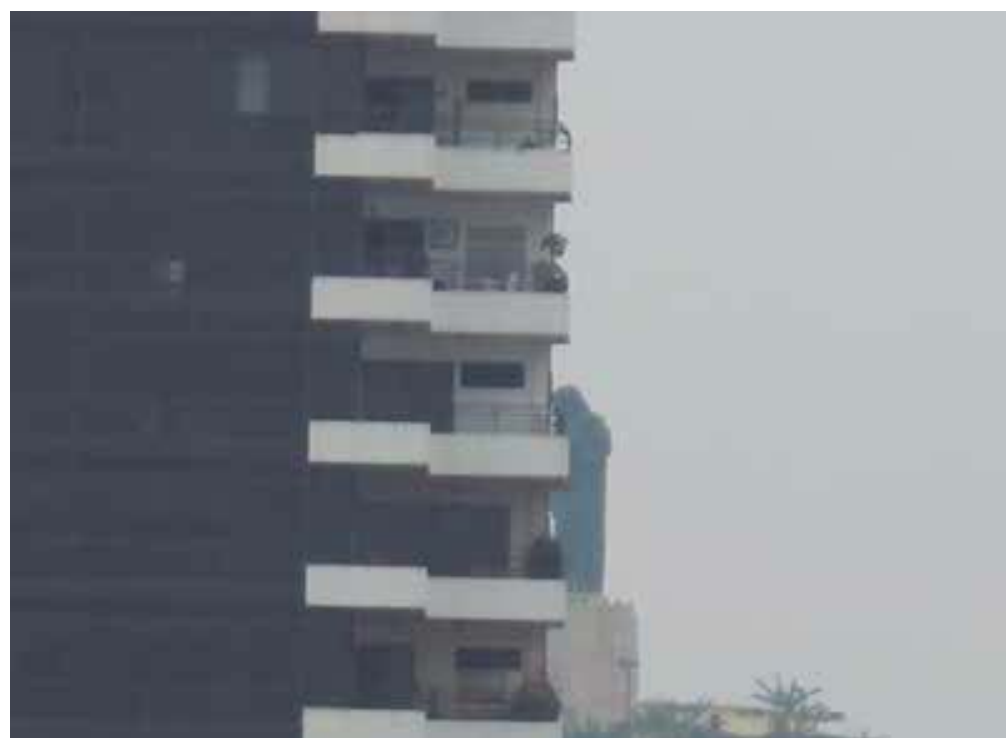
otro estado, salir del asombro y, seguramente, entrar a otro, dependiendo de los afectos sobre ese objeto de amor. Un ejemplo que recordé en ese libro: el pino es un árbol, pero en la navidad se vuelve el "arbolito de navidad". Lo que ha cambiado no es el pino, sino que ha ocurrido una encarnación o incorporación de sentimientos y ritos sobre ese objeto real para transformarlo por un período muy concreto, la navidad, en un nuevo objeto estético. Pasada la navidad se pierde el poder estético y ya ni siquiera es un árbol, sino un pobre chamizo que dejó de producir asombro.

Estudiar los imaginarios es buscar esas situaciones de asombro social, que, sobra decirlo, no solo serán de lo bello, sino que provienen de distintas fuentes de los afectos sociales, de la estética. Hay más producción imaginaria en la media en que dominen en la percepción los sentimientos sobre juicios racionales: rabias, venganzas, odios, anhelos, esperanzas. Y puede ocurrir que un hecho no pueda ser imaginado socialmente, como pasa en Colombia, donde ha habido tanta dificultad para crear un "imaginario de paz" frente a los de la guerra, que siguen dominado. Habrá muchos motivos de índole social e histórica para que eso ocurra, para que el bien más deseado, la paz, no pueda ser imaginado de modo colectivo y de manera relevante.

Así que en castellano asombrar me da exacto el sentido de lo que quiero decir, el asombro es hijo del fantasma urbano y luego lo rodea y representa. 
En las traducciones al inglés y al portugués ha habido mucha discusión. Al final en inglés quedó astonishment como una high admiration, se pensó en to shade, darken pero astonishment nos daba todos esos sentidos y es una palabra fuerte que se debe pronunciar tomando aire (dígala y verá...). En portugués, quedé sorprendido porque el título del libro fue traducido como Imaginários: estranhamentos urbanos. Me explicaron los editores que en Brasil asombro se asocia más con espanto, mientras que estranhamentos se vincula más con extrañar, extrañeza, como causar sorpresa y quedar lelo. Fíjese cómo cada lengua posee sus modos de nombrar el asombro, pero destaco que es una palabra que no tiene traducción inmediata, simultánea, sino que se escapa, como pasa con todas esas expresiones que tocan la vida psíquica profunda. Y un último asunto a tener presente: no hablo del asombro individual sino social. No hay imaginarios individuales.

P.V. ¿De cuáles fundamentos y teorías se nutre su teoría de los imaginarios urbanos? Teniendo en cuenta la importancia del componente estético en la conformación del corpus de sus investigaciones, ¿cómo se relaciona con otros enfoques como el arte contemporáneo, la crítica literaria y los estudios culturales?

A.S. Los que menciona puntualmente son campos entrelazados. El arte contemporáneo ha evolucionado a un arte de pensamiento, como lo explico en mi libro de Atmósferas ciudadanas: arte, grafiti y nichos estéticos (2014), y en esto corresponde a una alta producción mental como los imaginarios urbanos. Uno de sus teóricos, Borys Groys, en la parte operativa de la puesta de una obra, destaca que lo más propio del arte contemporáneo es la instalación, su forma más señera. Estas obras se ubican —aunque sólo sea temporalmente - en el contexto fijo, estable y cerrado de un "aquí y ahora" topológicamente bien definido. Esto es algo propio también del imaginario urbano que produce sus sentidos en una localización, no en una globalización, pues los imaginarios son de las comunidades concretas. Otra cosa son los sentimientos universales como el amor, el odio, la esperanza; pero cuando se encarnan lo hacen en un contexto único y con personas únicas. La tradición de los estudios culturales, en especial en la línea sajona, reúne dentro de sí una buena sociología de pensamiento estético, las artes visuales, la crítica literaria de origen semiótico. En fin, los imaginarios conforman aspectos de esa nueva tradición. De hecho, está por salir una revista monográfica sobre visualidades de la reconocida universidad MacGill de Canadá, con una fuerte raíz en los estudios culturales (Journal ofCross-Cultural Image Studies), editada por un especialista muy alerta y al día en iconografías, el profesor William Straw. El número está dedicado a visualidades (Imaginations on The Visuality of Scenes) y se incluyó un ensayo de mi estudio de los imaginarios como parte de esta perspectiva visual. 
Diría que los estudios de imaginarios son tan contemporáneos como los otros campos que usted menciona. Sibien los estudios de imaginarios se inician en el campo analítico, fíjese que la palabra imaginarios no está en la obra de Freud, solo apareceluego por primera vez en Lacan ("La subversión del sujeto y dialéctica del deseo", en Escritos, 1960) yluego en Metz (El significante imaginario, 1979). Tampoco estaba en los textos del marxismo nien otras corrientes dela antropología ola lingüística. Nace, como ocurre con otras palabras vinculadas a lascienciasyalahermenéutica,cuandoen elavancedeunateorizaciónapareceel vacíode un concepto o una palabray hay quecrearla; en micaso, propuse porprimera vez el concepto imaginario urbano en milibro Imaginarios urbanos (1992) . Cinco años después García Canclini publicó sus Imaginarios urbanos (1997), y así va haciendo carrera la expresión y el concepto. Pero es algo muy reciente y en proceso de decantación.

Sin embargo, el campo transdisciplinar que propongo de los imaginarios urbanos tiene un fuerte soporte en tres orígenes: lógico, psicoanalíticos y filosófico. En lo primero, como lo podrá constatar, traigo la obra de Peirce como soporte semiótico, es su concepción triádica en la que se incluye el interpretante como ejercicio permanente y dinámico de significar (distinto a la noción semiológica europea más de carácter lingüístico y estático), lo que me da luz sobre los imaginarios como modos dinámicos de estar significándose y modificándose. No en balde mi modelo de percepción es triádico, pero no perciano, es una propuesta que lo toca pero no se define en él.

El origen psicoanalítico viene de mi propia formación con Ch. Metz, quien "tradujo a Lacan" para iniciar su propia ruptura y entender que el cine no es lenguaje, como él mismo lo había dicho, desde la semiología (Eco, Guiraud...), sino que parte de un significante imaginario (en deuda con Lacan). Luego de Metz el cine es producto y consecuencia de "tres máquinas" interactuantes: la tecnológica, la industrial y la mental proyectiva del espectador. De ahí parte mi idea de los imaginarios urbanos, como lo expliqué en una entrevista (María Elvira Ardila, Museo de Arte Moderno de Bogotá MAMBO, 2008), los imaginarios urbanos vienen del cine, nada menos. Y la tercera pata y pista es el deconstruccionismo de Derrida, fui su alumno y con él escribí quizá una de mis obras que más quiero: Álbum de familia: la imagen de nosotros mismos, donde puse en juego la deconstrucción en la percepción de las fotos de los álbumes junto con una mirada de valoración psíquica. Elálbum es un archivo en permanente deconstrucción y su valoración semiótica y valía de cada colección o álbum se da cuando lo volvemos a ver y así se actualizan sus sentidos. Aclaro que mi tesis doctoral se terminó en 1996, cuando dominaba el álbum de fotos análogas y de papel, lo que cambiará el sentido en esos nuevos archivos digitales.

P.V. Usted habla de un modelo tríadico de encarnación, podría explicarnos ¿cuáles serían los modos de producción social de lo imaginario? 


\section{¿Cómo se vincula con la metodología que propone para abordar los ima- ginarios urbanos?}

A.S. Sí, se trata también de un modelo triádico. He llegado a la conclusión que existen tres acercamientos tutelares de producción social de imaginarios urbanos en cuanto a la construcción de urbanismos ciudadanos. La pertinencia de cada situación estará dada por el resultado de relacionar los términos considerados $\boldsymbol{I}$ (Imaginado) y $\boldsymbol{R}$ (Real). Así el modelo triádico se recompone en tres situaciones de "percepción de la realidad", en la que domina una u otra de las tres entradas del mismo modelo, y quizá de este modo sea más clara la pretensión lógica que asumo.

Si usted me lo permite, intentaré demostrarlo con imágenes visuales, siendo ellas mismas la escenificación de un imaginario. Aclaro de nuevo que los términos pueden tener relación con las terminologías de Peirce o Lacan, pero no es esto a lo que aludo. En mi caso la $I$ es lo Imaginado, pero la $\boldsymbol{R}$ no es lo Real de Lacan ni The Fitness de Peirce, pues tomo lo real como "la realidad", lo que está por fuera de mí, significando. Pero claro: al ser percibido por mí, entra en lo imaginario, pues lo que se llama realidad ya es un imaginario encarnado.

Se dan, entonces, tres posibles situaciones para concebir este modelo, por tanto toda percepción social debiera entrar en una de ellas. Para mayor claridad, lo refiero en imágenes que represento como ejemplos en cada caso.

\section{$\mathbf{R}$ Situación 1: para significar que el primer tipo de realidad se cons- $\mathbf{g}_{\mathbf{1}=\mathbf{I}} \mathbf{R}$ truye cuando lo Imaginado es dominante $\mathrm{y}$ Real lo potencia, por tanto $I$ se eleva a la $R$ potencia.}

Ocurre cuando un hecho, un objeto o un relato no existe en la realidad empírica comprobable, pero una colectividad lo imagina y lo vive como realmente existente, esto ocasiona una gestualidad ciudadana. Caben acá las situaciones más evocativas y menos llamadas a realización empírica, por tanto es la situación de mayor capacidad detonante del fantasma urbano.

Un caso que suelo citar se da en México DF. La Avenida Hidalgo, en el centro dela cuidad, solía identificarse con un olor fétido por ser lugar de paso de ciertas aguas negras sin canalizar. Pero el gobierno local solucionó el problema en 1999 y los malos olores desaparecieron en la realidad objetiva, sin embargo siguen siendo percibidos, aun hoy en día, por algunos ciudadanos que no pueden evitar el recuerdo que se hace real en cada percepción y contagia socialmente a algunos ciudadanos más jóvenes que nunca vivieron esehecho. Es el típico “olor imaginado". Esto pasa en la vida cotidiana, vemos a una mujer que asociamos de inmediato a un cierto perfume y lo sentimos. Muere una persona querida y entramos a su cuarto y sentimos sus olores característicos. En fin: la realidad es imaginada y por eso incierta. 
En Valparaíso, ciudad ubicada en el litoral central del territorio continental de Chile, se hizo un puente en 2002 sobre el lecho y las playas aledañas del mar Pacífico para acercar un trayecto terrestre, pero nunca se adelantó la obra real de conexión y ha quedado como testimonio visual de apenas un "puente imaginado" (foto 3) que la gente visita y toma fotos para imaginar cómo pudo haber sido si de verdad se hubiese terminado. Y en ese imaginar se afecta la percepción de ese objeto real.

Figura 3: Puente imaginado, Valparaíso

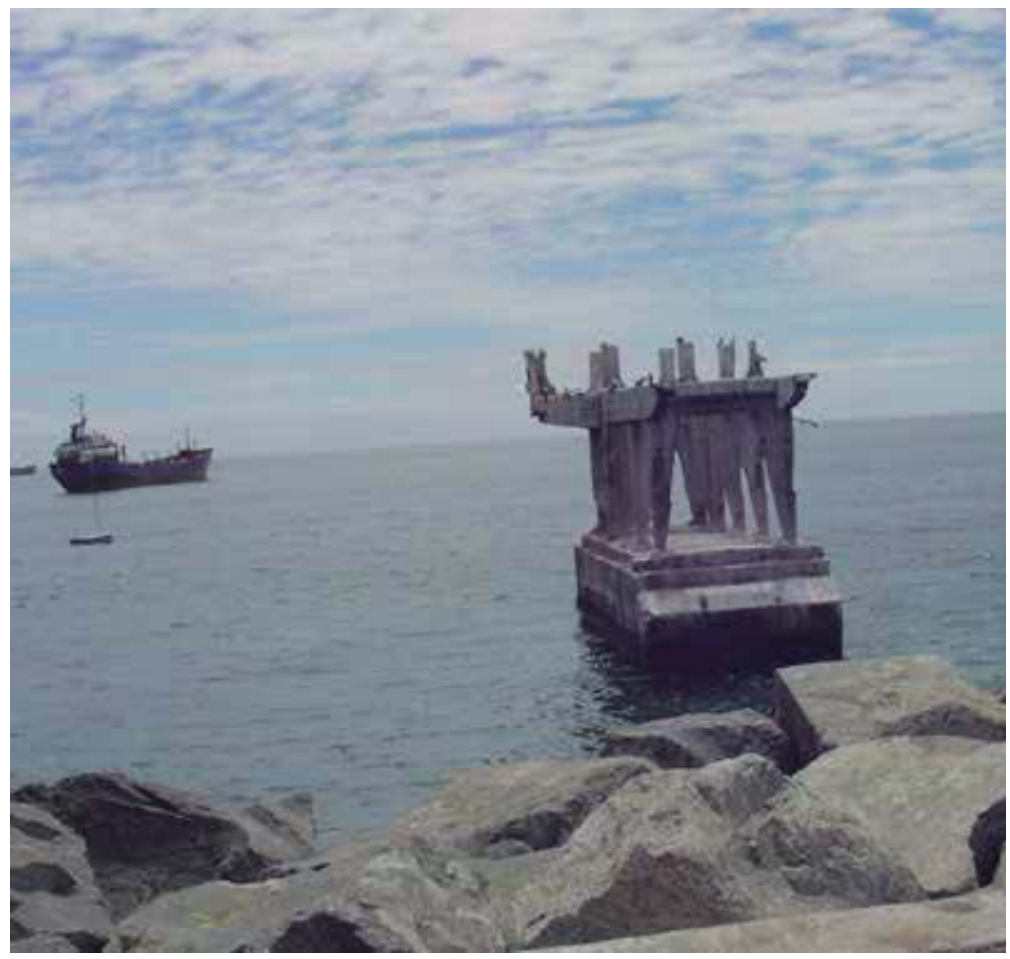

La foto 4 es propia de esta forma de $\boldsymbol{I}$ a la $\boldsymbol{R}$ potencia. En la Avenida 9 de Julio de Buenos Aires (2008) se puede percibir el desgarrón imaginario que intenta el publicista al querer decirnos, casi susurrando, lo que puede pasar adentro, en esos apartamentos, con la bella modelo incrustada literalmente en la vivienda, en un escena que bien podría denominarse sexo y arquitectura. 
Figura 4: Arquitectura y sexo, Buenos Aires

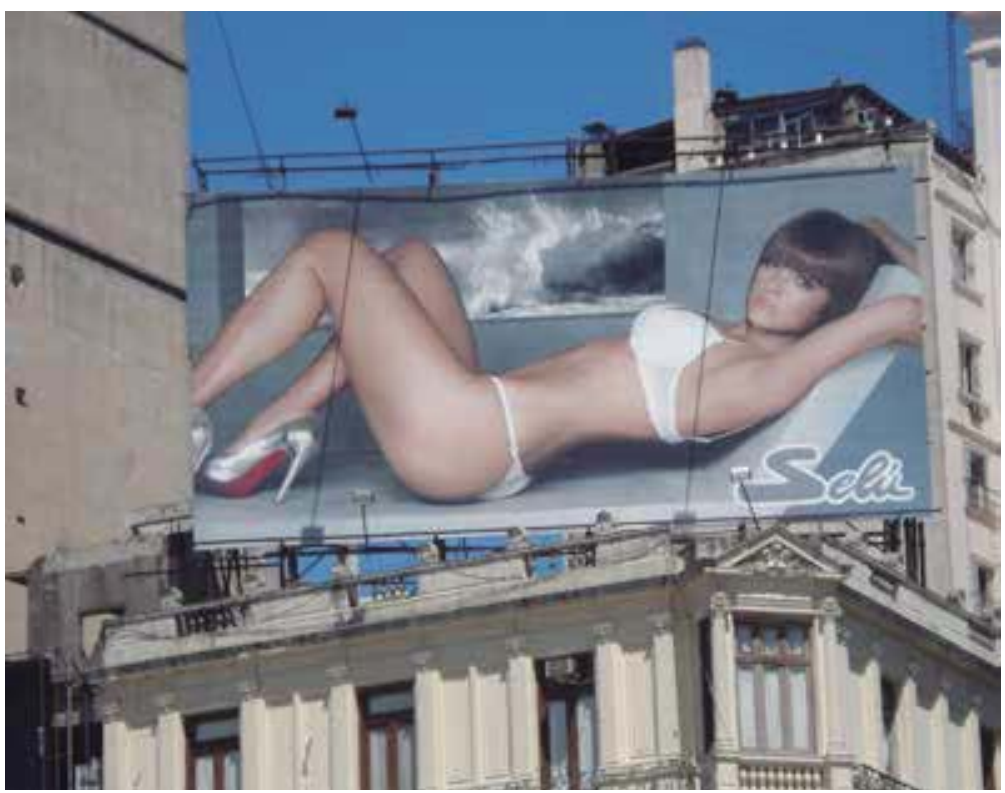

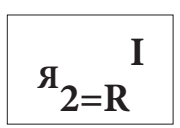

Situación 2: para significar que el segundo tipo de realidad se construye cuando lo Real es dominante y lo Imaginado lo potencia, por tanto $R$ se eleva a la $I$ potencia.

Se trata de un objeto, un hecho, un relato o imagen que existe empírica y referencialmente, pero no se le usa ni evoca socialmente por una urbe, toda la colectividad o algún sector de ella. Caben acá, al contrario de la anterior, las situaciones más empiristas y realistas, y ayudan a distinguir los estados de olvido de sitios, objetos borrados dela memoria, hechos históricos apenas recordados, lugares no visitados. La invisibilidad ciudadana.

Es el caso del centro de la ciudad de Montevideo, donde los autores de Montevideo imaginado comprueban que "sólo existe en la realidad" (Álvarez $\&$ Hubert, 2005), y no en el imaginario para la mayoría de la población que ni lo visita ni lo nombra siquiera. A medida que el barrio del Centro fue perdiendo en esa ciudad el valor de reconocimiento ciudadano para efecto de usarlo, visitarlo o caminarlo, ese protagonismo pasó al paseo de la Rambla, que viene a ser como su extensión moderna, el lugar que concentra la mayor densidad de cualidades positivas del imaginario montevideano.

Por otra parte, en la foto 5 se puede ver una "realidad invisible" para la sociedad en su cotidianidad; que, no obstante, la foto la hace patente: la división social en el reparto del territorio entre clases adineradas ylos sectores populares 
en Caracas, revelados por la relación Este-Oeste de esta gran avenida. Algo parecido ocurre en la foto 6: en São Paulo una mujer seca su ropa en pleno centro tumultuoso, detrás de la Catedral San José; como en una burbuja, como que nadie fuese consciente de lo que ella hace y se hiciese invisible.

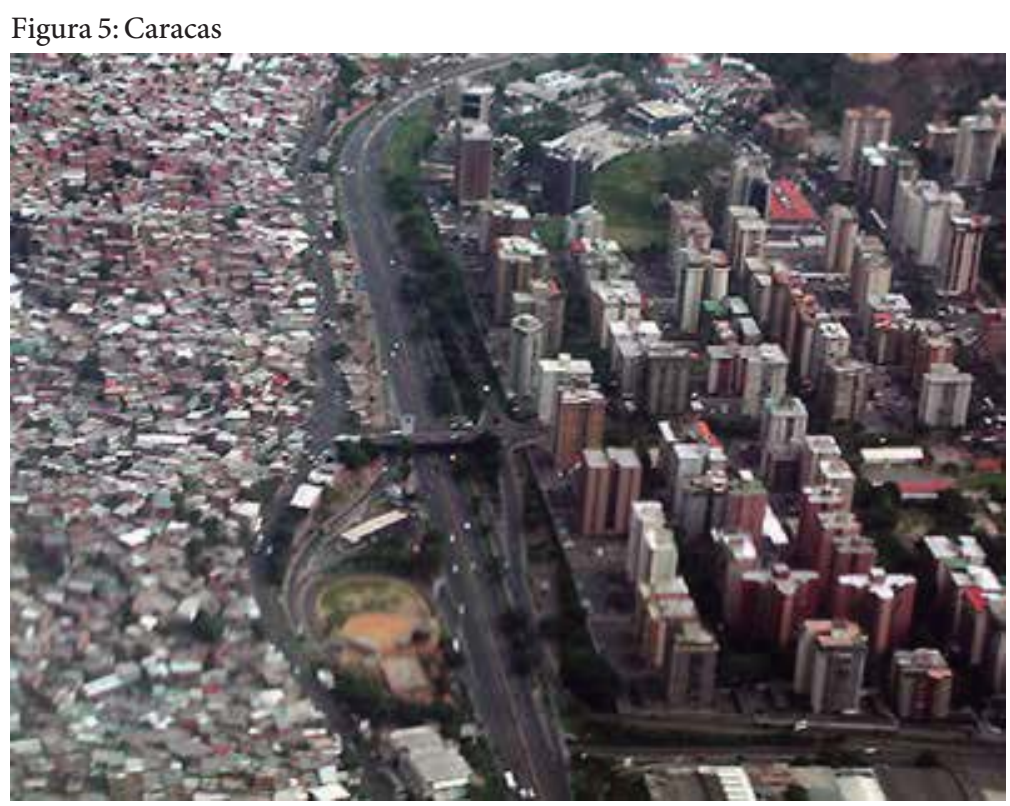

Figura 6: Lavando ropa, São Paulo

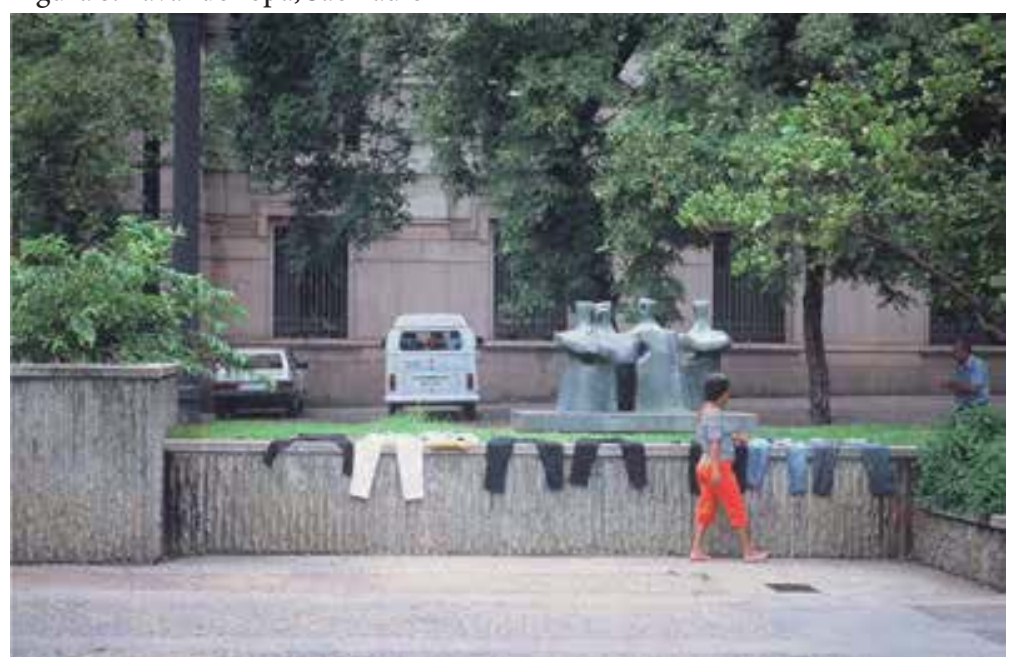


Como puede apreciarse, esta situación 2 del modelo triádico ubica un hecho factual que no amerita recreación discursiva para una colectividad o un grupo de ella, y genera un "abandono perceptivo" por parte de algún grupo significativo de ciudadanos. Se produce una especie de negación sobre un objeto de una parte de la ciudad o de un hecho social, y lo negado sigue existiendo tan solo en la realidad.

\begin{tabular}{l|l}
$\mathbf{9 3}=\mathbf{R}(\mathbf{I})=\mathbf{I}$ & $\begin{array}{l}\text { Situación 3: para significar que el tercer tipo de construcción de } \\
\text { realidad opera cuando } \mathbf{I} \text {, lo Imaginado, es equivalente a } \mathbf{R}, \text { lo } \\
\text { Real, queen la dinámica delosimaginarios se reconstituye como }\end{array}$
\end{tabular} I', habiendo sido enriquecido en su sentido por $\boldsymbol{R}$. Se usa I' para señalar que es similar, pero no la misma $I$ inicial pues ha incorporado o ha sido afectada por una nueva interpretación de lo Real que ocasiona la re-significación de $I$.

La Paz, en Bolivia, es una delas urbes con más uso dela calle como expresión estética y política, y esa profunda relación entre lo real y lo imaginado, entre el accionar del arte y de la protesta, entre la evocación y la realidad festiva lo destaca Carlos Villagómez, autor de La Paz imaginada. En esta ciudad, dice, no se han acallado los ritmos y los bailes ancestrales que se recrean año tras año en las variadas entradas folclóricas que "toman por asalto la ciudad" y las plazas y calles convocadas por motivos religiosos o culturales (foto 7).

Figura 7: Chola bailando en el mercado

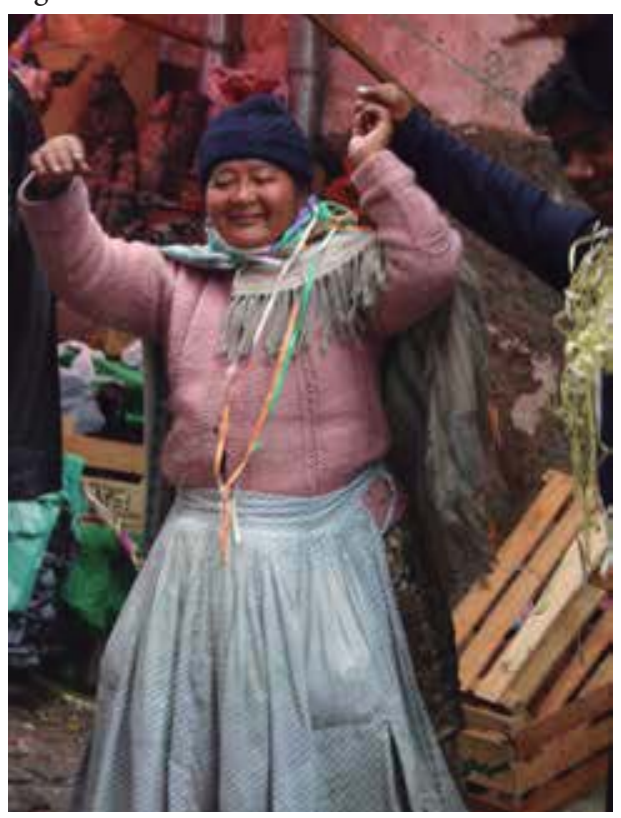


Dentro dela misma situación 3 se puede apreciar como relevantes a aquellos lugares peligrosos percibidos como tales por la colectividad en coincidencia con las estadísticas empíricas. O sea, los ciudadanos saben de los lugares peligrosos y su percepción coincide con los datos reales, estadísticas diarias de la misma policía ciudad, como lo demostramos en Bogotá imaginada, durante la intervención de algunas alcaldías (1992-2002) que basaron su gestión en estas certezas de percepción para adelantar planes exitosos de seguridad ciudadana ${ }^{1}$.

Cuando intentamos llevar este modelo a la Caracas del inicio chavista, o sea, comparar la percepción imaginada de los ciudadanos, el crimen y sus sitios de peligro, con los sitios reales donde de verdad se cometían, encontramos que no había coincidencia: esto quiere decir que los caraqueños entonces (2005) no sabían detectar dónde se cometían en escala los homicidios; por tanto donde creían que los había no era cierto, correspondía tan sólo a una percepción imaginaria que pasaría más a encajar en el modelo que propongo a la situación 1: cuando lo Imaginado es dominante y lo Real lo potencia, situación descrita en la relación $Я_{1}=\mathrm{I}^{\mathrm{R}}$, de amplio dominio, como ya dije, del fantasma urbano.

El autor de Sevilla imaginada, Pedro E. Romero, en su excelente y reconocido trabajo de archivística, nos aporta dos fotos (8 y 9) que toman como fondo el ícono de la ciudad: la Giralda, pero en distintos momentos: durante la falange española de orientación fascista en los años 30 del siglo XX y Guardia Republicana del General Franco años después. Se nota que es el mismo sitio, pero transformado por una ideología que la hace otra realidad.

Figura 8: Giralda, falange española años 30

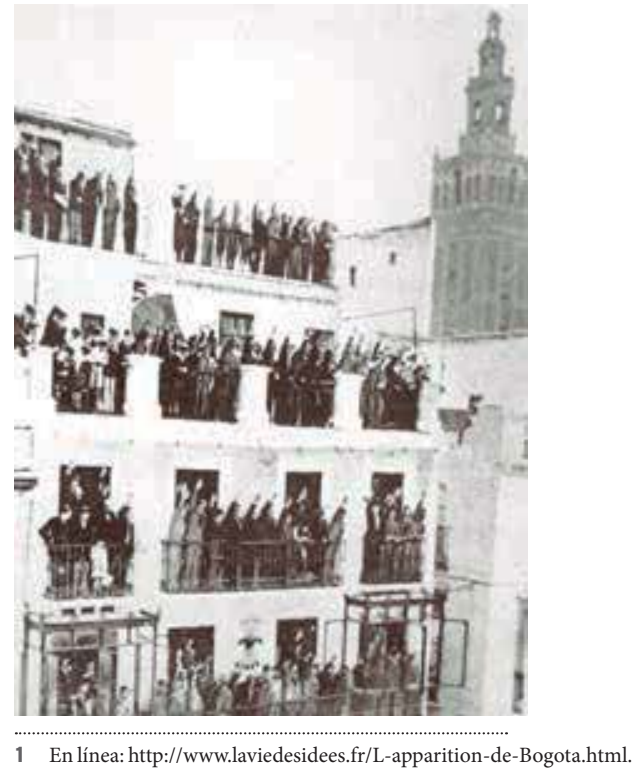


Figura 9: Giralda, guardia republicana

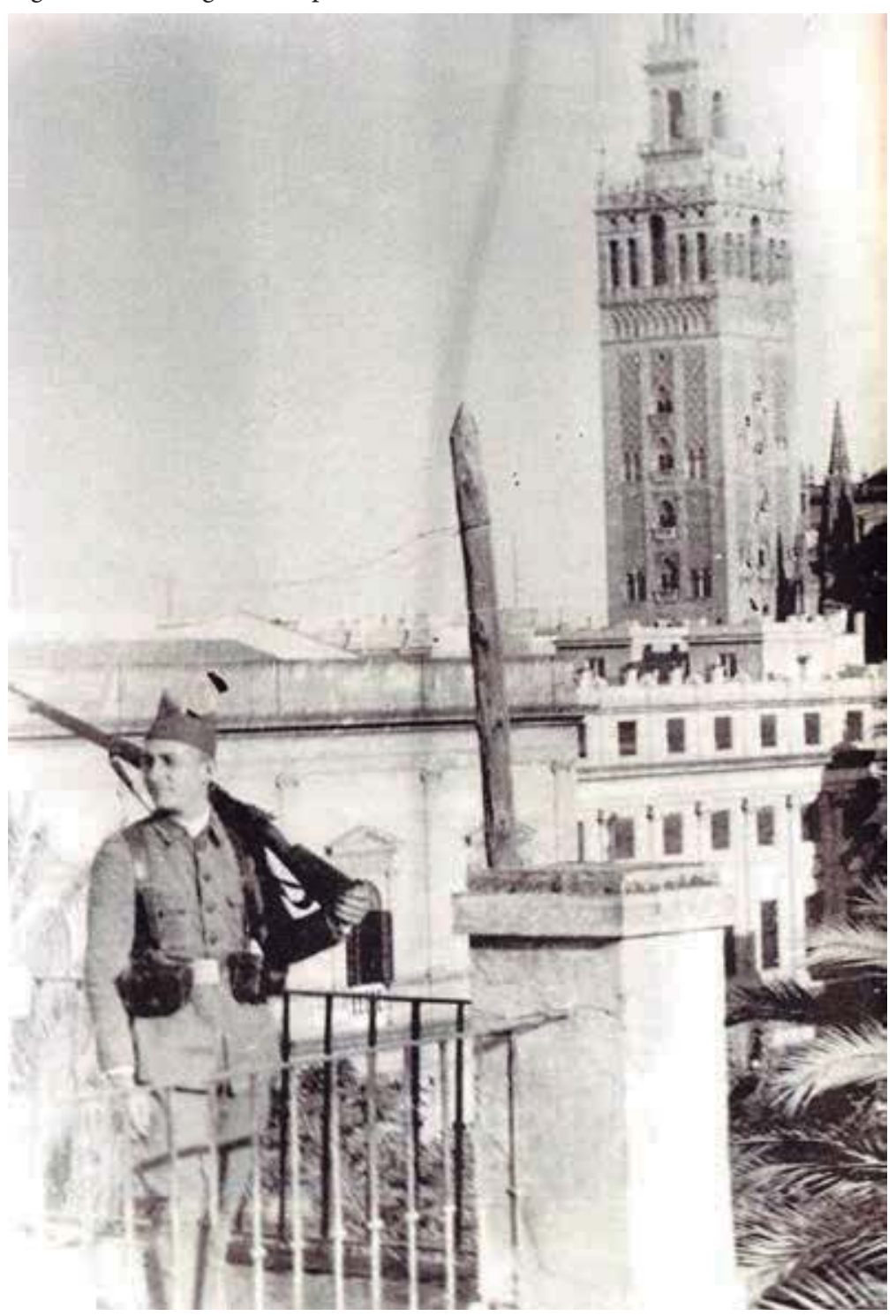

Sirve este ejemplo para sostener la dimensión temporal de los imaginarios sobre su misma espacialidad. Incluso me animo a reiterárselo así dado que esta entrevista es una revisión de mis puntos de vista sobre lo urbano de la ciudad: mientras la antropología del lugar, como en la dimensión de M. Auge, se basa en el espacio de una ciudad, al que se teoriza, esta dimensión de los imagina- 
rios se fundamenta en el tiempo, en su movimiento y circulación, entonces no en el lugar sino en el sitio: los ciudadanos no están pegados a un lugar para significarlo, sino que se sitúan desde su percepción. En mi perspectiva, donde priman los sujetos, su análisis parte de los ciudadanos: el urbanismo ciudadano.

Cada nueva situación urbana puede recomponer los croquis ciudadanos existentes, pues las fronteras entre lo real y lo imaginado son muy débiles, sobre todo cuando alguna conmoción afectiva se hace presente. Pero la situación 3 es aquella en la cual los ciudadanos logran un buen equilibrio de lo real con lo imaginado: es real porque así mismo se lo imagina una colectividad concreta.

En síntesis, reitero que con las aclaraciones descritas hemos fortalecido el paradigma de la "ciudad imaginada" para referirnos entonces a aquella que construye el urbanismo ciudadano, porque se la imagina y la usa o la evoca aun cuando no existe: IR, o porque existe pero no se la imagina que existe: RI o bien porque existe y se la imagina y la usa como existente: $R(I)=I$ '. Con esta modelización se hace ver que lo imaginario no es irreal o sólo describible como hecho en la fantasía. El imaginario es constructor de la realidad social y debemos entonces, más bien, explicitar el proceso de cómo se "incorporan" los imaginarios sociales en los entornos físicos de la ciudad, y así proyectarlos como expresión de culturas ciudadanas.

P.V. El proyecto internacional "Ciudades Imaginadas" que usted dirige, trabaja con la misma metodología sobre casi 30 ciudades del mundo, gran parte de ellas latinoamericanas. ¿Existe algo propio latinoamericano? ¿Cuáles rasgos de los imaginarios urbanos se pueden encontrar en ciudades de diversas regiones? Es decir, ¿qué hay de común en los imaginarios urbanos contemporáneos?

A.S. En la bienal de São Paulo de 2006 fui invitado a participar sobre la obra del artista Lars Mathiseen, curada por Lars Ban Larsen, y se escribió un libro (Cat, Microwave, Tinfoli) en donde, en una parte, yo trabajé los imaginarios globales respecto al arte. Un aporte que se me dio para la redacción de mi ensayo fue aplicar por la empresa Gallup encuestas de percepción en varias ciudades del mundo. El resultado fue que el imaginario dominante, en gran parte de la muestra, era el miedo. De ahí la relación destacada por varios analistas entre miedo y política: los vemos en Bush, ahora aún más en Trump o en varios presidentes de América Latina que promueven como estrategia de gobierno el miedo. En todas las ciudades de América Latina que he estudiado con equipos locales, claro, ese es el sentimiento dominante, el miedo. Cambian, sí, sus motivos. Por ejemplo, en México hay miedo al metro, a que se quede uno como pasajero sin aire; en Caracas chavista de hoy hay miedo al futuro; en Buenos Aires, las autoras Mónica Lacarrieu y Verónica Pallini hablaban del miedo a ciertas minorías que llegaban de países vecinos. Por ejemplo, esto se puede apreciar en la foto 10 . 
Figura 10: Exilio, Buenos Aires

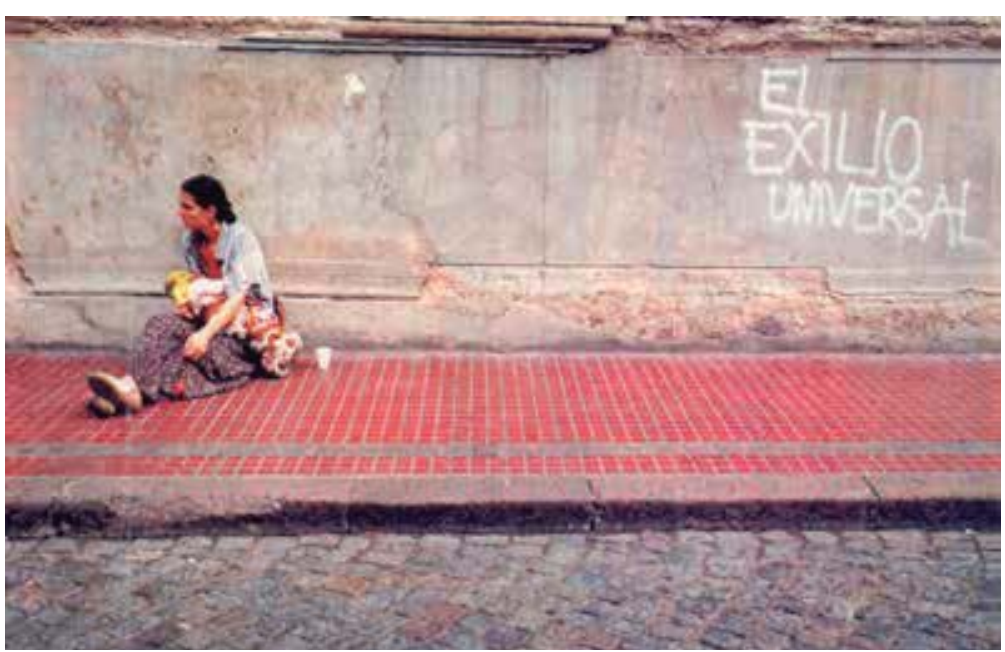

El otro imaginario que destaco es que todas las ciudades capitales de América Latina se creen más grandes de lo que son, con la única excepción de Montevideo, tal vez se debe a su rápida formación o también a una situación de poder, pues se imagina que con más habitantes serían ciudades más fuertes y poderosas. Estas proyecciones se dan mucho entre ciudades rivales.

Y un tercer imaginario es el de los sabores locales. Esta tendencia se inició en México, siguió con mucho éxito en Perú y hoy se riega por todos y cada uno de los países. Hoy tenemos cada urbe buscando sus orígenes y sus sabores locales. Ahí puede ver las relaciones entre imaginarios de nación y turismo, por ejemplo.

P.V. Sus indagaciones están orientadas a analizar las percepciones que los ciudadanos tienen de sus ciudades. Sin embargo, podríamos considerar que este es uno de los aspectos o puntos de vista sobre las ciudades y la vida urbana. ¿Cómo concibe las relaciones entre los imaginarios urbanos de otros actores sociales como pueden ser los gobiernos, el empresariado, las instituciones o los movimientos sociales?

A.S. En los estudios de los imaginarios urbanos, en la dimensión que lo hacemos con mis colegas que forman parte de este proyecto, no solemos entrar a planes de gobierno o de alcaldías. Más bien se trabaja desde instituciones, digamos neutras, sin un interés concreto, sea político o comercial, como son universidades o centros de investigación. Deninguna manera hay algún interés en publicitar o en apoyar una corriente de gobierno. Esto hace a estos estudios más académicos, pero también más libres en su accionar como arte público, 
pues usamos medios para impactar con nuestros resultados en las comunidades concretas. Si mira nuestra página web en desarrollo ${ }^{2}$ o en nuestro canal de YouTube: imaginarios urbanos ${ }^{3}$, podrá ver que, si bien solo hemos subido una parte mínima de los datos que poseemos (pues solo van subidos menos del 10\%), sí se logra apreciar que el proyecto produce fotos, clips, archivos de postales, estudio de álbumes de familia, etc. Es nuestra manera de hacer política, pues queremos devolver a la ciudad que sometemos a un estudio cómo comprendimos sus imaginarios urbanos a fin de que se fortalezca el criterio identitario; también porque de este modo se generan visiones dela urbe, lo cual la enriquece plásticamente.

Haría esta síntesis de cómo han evolucionado nuestros estudios delos imaginarios urbanos: si bien se inicia con un interés en lo comunicativo, luego pasamos por una fase de arte, cuando asistimos invitados a célebres exposiciones, como Documenta 11 en Alemania o la Bienal de Venecia y la de São Paulo. Pero en los últimos años, reconozco, viene apareciendo un interés político, sin dejar la base académica, en algunas de los grupos locales como en la ciudad de Pereira, en Colombia. Allí su coordinadora, la Dra. Olga Bedoya, hace un trabajo muy útil, digamos, pues ha instalado terminales en centros comerciales de la ciudad para que los ciudadanos respondan en tiempo real preguntas prácticas como: qué sitio de la urbe siente peligroso ese día o indaga por escalas de percepción cromática u olfativa de la urbe. Y estos datos los trabajan en su universidad; que, al ser pública y de la región, puede incidir en el desarrollo de la urbe con los organismos oficiales.

Lo anterior podría ser el inicio de una nueva orientación del "proyecto imaginarios" con gobiernos y empresarios. Esto nos podría llevar a un anhelo primordial del proyecto, que es acercar el deseo ciudadano a su realización social: ya lo hacemos a nuestra manera, usando medios, literatura, música como se puede ver en nuestra página ${ }^{4}$. O sea, hay una parte del proyecto y de su programa de "ciudades imaginadas" que es creativa; nosotros mismos producimos obra, fungiendo de artistas investigadores, para que circulen videos, colecciones de fotos de emblemas urbanos o de grafitis y arte urbano de las ciudades, sus álbumes de familia, etc. En su parte política se trataría de profundizar.

P.V. ¿Cómo se relaciona lo que usted denomina urbanismos ciudadanos con el urbanismo participativo o el urbanismo social promulgado por arquitectos y urbanistas? $O$ en todo caso, ¿ ‘cómo puede enriquecer la perspectiva de los imaginarios urbanos a los proyectos de participación ciudadana?

A.S. Le transcribo lo que dicen dos de los críticos y curadores de la Fundación Antonio Tàpies de Barcelona, sobre mi trabajo:

2 En línea: http://datos.imaginariosurbanos.net/collection-tree

3 En línea: https://www.youtube.com/user/imaginariosurbanos

4 En línea: http://datos.imaginariosurbanos.net 


\begin{abstract}
Armando Silva propone en sus archivos un acercamiento a una de las formas en las que se ha querido entender cómo los ciudadanos representan sus ciudades a la vez que construyen nuevas relaciones con ellas (...). Frente a los relatos hegemónicos ofrecidos por los diversos gestores de lo urbano, que suelen materializarse en imágenes acabadas, maquetas de cartón, piedra y cifras cerradas, este proyecto plantea la posibilidad de construir micro-relatos, a menudo conflictivos, a partir de residuos, rastros y restos, tanto físicos como virtuales, dejados por la vida intensa dela que se nutren los diversos modos de ser urbano. Porque los imaginarios, como base de un urbanismo de los ciudadanos, permiten estudiar los registros de la participación ciudadana en la construcción simbólica de la ciudad, con el fin de entender sus usos y definir otras formas posibles de habitar (Nuria Enguita \& Jorge Blasco, 2009) ${ }^{\mathbf{5}}$.
\end{abstract}

Creo que de eso se trata el urbanismo ciudadano, o sea, que no está en la ciudad física, sino que habita en la mentalidad de los ciudadanos. En mi perspectiva, divido la ciudad física de la mentalidad con la que se vive, este es el urbanismo que forma la base para los imaginarios. La ciudad física se vive desde cómo se la imagina. Por esto uno de los principios de este enfoque es que la ciudad imaginada antecede a la ciudad física. Si toma uno de los imaginarios más poderosos como es el miedo, que ya mencioné, y si hay una ciudad que se caracteriza como ciudad de peligro, tal cual el imaginario que se construyó de Medellín alrededor de la violencia de los narcotraficantes en los 80 o luego en Ciudad Juárez en México, en este siglo, al arribar uno a estas ciudades, así hayan bajado índices de criminalidad de manera muy eficiente se pasea y se visita desde el temor. Si uno pregunta a cualquier ciudadano qué ciudad es más segura entre Medellín y Washington, por ejemplo, todos dirían que la segunda. Sin embargo, en el 2014, mientras en Medellín hubo 32 muertes violentas por 100 mil habitantes, en Washington se registraron 60; o sea, más o menos el doble. Con esto quiero decir que la percepción del urbanismo ciudadano es de base imaginaria, a lo cual contribuyen los medios, las noticias, la literatura, el cine, en fin... la vida en acción.

Las relaciones entre urbanismo ciudadano y el urbanismo de la arquitectura salta a la vista y de seguro serán acciones cada vez más concertadas. Construir un barrio o unos edificios sobre la base del miedo es reforzar este sentimiento que termina por aislar el sitio y quebrar la ciudad como unidad. La foto 11, en Caracas chavista, no es una foto del edificio Tamayo, sino del terror de habitarla. Y hoy Caracas está así, enrejada, aislada. Cuando finalice el gobierno chavista y se quiera reconstruir Caracas habrá que apostar a su urbanismo arquitectónico para mostrar una ciudad sin miedo y que nuevos sentimientos contagien.

5 Nuria Enguita y Jorge Blasco, en Catálogo de la exposición Imaginarios urbanos: proyecto de Armando Silva, Fundación Antoni Tápies de Barcelona y Banco de la República, Bogotá, marzo de 2009. En línea: https://www. fundaciotapies.org/site/spip.php?rubrique676 
Figura 11: Tamayo \& Cía. SA, Caracas

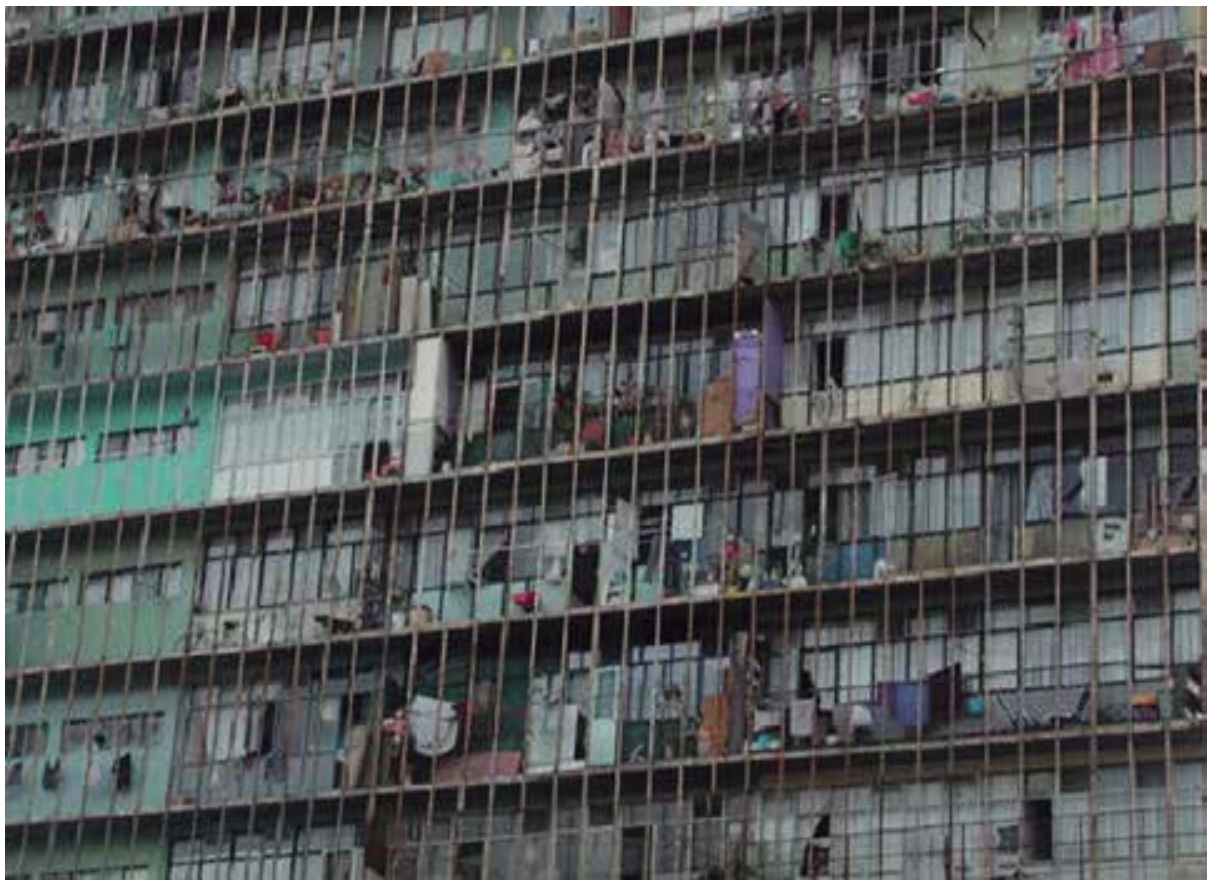

El Grupo Atlas de Alemania estuvo en Documenta 11, en 2002, al tiempo conmigo. Ellos, un grupo de teatreros y arquitectos, plantean construir casas a partir de cómo se las imaginan sus clientes. Empezaron con viviendas de bajo costo y pedían que imaginaran sus viviendas: zonas de estar, cocina, de higiene, etc. Sus construcciones debieron ser extrañas, pero respondían a los deseos de sus habitantes. Esto se puede sofisticar y acercar más la vivienda a los deseos de sus moradores, y no dejarla solo al criterio del profesional. O mejor, como hace muchos años lo pensó Christopher Alexander en su bello libro La ciudad no es un árbol, donde la labor del profesional es poner sus conocimientos y la técnica al servicio de los usuarios; no como es hoy, donde estos no intervienen en "hacer su casa".

P.V. ¿Qué se pierde y qué se refuerza de la Identidad Urbana ante los fenómenos contemporáneos como la globalización, el turismo, la patrimonialización, la estandarización o la tematización?

A.S. Todos esos fenómenos que me cita se nutren de imaginarios de alta resonancia. Ya se hahablado dela globalización imaginada (Canclini, MacCannell y otros) o qué decir del turismo que, sin duda, es muy sensible a imágenes como seguridad, distinción, placer, novedad, etc. Si hay un atentado en una 
ciudad la gente cancela su viaje de placer, como ha ocurrido en París (2015) o en Londres (2017) por el EI. O si hay una pandemia como la aviar en México (2009-2010): bajó el turismo un 10\%. El turismo es uno delos grandes imaginarios sostenidos en el paradigma de "vida feliz y algo de riesgo", y hoy representa cerca del 10\% de los ingresos mundiales.

De otro lado, contrario a lo que se pensó de una globalización que arrasaría con lasidentidades locales, hoy el asunto se ha procesado más yla globalización se entiende más en lo económico - y aun esto también se está poniendo en duda-, y en lo tecnológico. Las culturas locales, al contario, usan las mismas tecnologías para mayor afirmación y puesta en escena. Le pongo como ejemplo las comunidades LGBTI; que en cambio de estar arrinconadas o "enclosetadas", usan redes, manifestaciones en calles y parques para hacerse ver y reconocer. Incluso se ha logrado interesantes avances para su reconocimiento.

Las comunidades geográficas, como ciudades o pueblos, se ven hoy favorecidas por campañas de búsqueda de sus antepasados, de sus memorias, de sus culinarias, de sus mitos. También usan las nuevas tecnologías y esto no significa globalización. No voy a desconocer que lo global afecta procesos, como por ejemplo una nación se prepara para recibir el turismo mundial. Solo hago notar la doble vía y que no se cumplió la promesa de la globalización de emparejar las culturas. El ser humano es complejo, tiene muchas defensas e inesperadas reacciones. La salida de la selva de las FARC por la firma de paz en Colombia hace que se llene de sensualidad y misterio ir a los terrenos desocupados, como llegar a nuevo mundo, y eso es ya un problema a resolver desde las culturas locales.

\section{P.V.¿¿ Considera que el marketing urbano incide de algún modo sobrelas percepciones ciudadanas de la ciudad?}

A.S. Claro está. Pero no es infalible. El marketing y la política han merecido en los dos últimos años grandes derrotas. En el Brexit en el Reino Unido, en EE.UU. con el triunfo de Trump o el triunfo apenas en el límite de Moreno, el candidato de Correa en Ecuador, son demostraciones de que fuerzas por fuera del marketing numérico están saltando a la escena pública.

En cuanto a la publicidad, se puede decir que uno de las aspiraciones del capital por volvernos sujetos consumidores triunfa: el hiperconsumo como lo llama Lipovetskiy. Lo que se ha llamado "fabricar consumidores" por parte de economistas como Thorstein Veblen, se extiende y el sistema ha logrado que aun en momentos de descanso de los ciudadanos, como fines de semana, se llenen con consumo y de ahí la importancia de los centros comerciales en las ciudades donde se ejerce ese "derecho a consumir". Pero no creo que sea una "conspiración" orquestada desde algún sitio concreto y secreto del poder, como lo denuncia N. Chomsky, dando la impresión de que unas pocas personas poderosas se hayan puesto en acuerdo explícito para encerrarnos 
en la compra incluso de objetos no necesarios. Se trata más bien de la forma como evoluciona un capitalismo voraz y depredador que irrespeta todos los principios de dignidad ciudadana.

Sin embargo, tenga presente que allí también se dan muchos movimientos sociales hacia la protección del medio ambiente, contra el maltrato animal, contra el consumo de carne. También se consolida una nueva mirada de corrientes espirituales como budismo, yoga, medicinas alternativas, slow food, slow city, etc. Algunos de esos movimientos usan las mismas redes para oponerse a la voracidad del capital y del marketing. Se habla de que la primera revolución industrial estuvo basada en la ingeniería, la segunda en la electricidad, la tercera en las tecnologías de la información y que la cuarta ya se ha iniciado sobre una economía de la creatividad (denominada "naranja"). Hoy en el mundo las industrias creativas producen el 5\% de la economía mundial con 150 millones de empleos; en ellas se trata de producir conocimientos con base en la cultura, música, artes, arquitectura, medio ambiente y las nuevas tecnologías.

El turismo tiene una fuerte tendencia hacia el ambiente que aprovecha los recursos naturales, etc. No quito que el marketing es muy poderoso y sabemos hoy que incluso ciencias de vanguardia como la neurociencia se usan para instalar el neuromarketing. Se puede decir, para concluir esta pregunta, que buena parte del consumo, del mercado y de las aspiraciones de muchos ciudadanos está apalancado por un imaginario poderoso de la época actual; como es el imaginario de la felicidad, la belleza y la juventud. En otros momentos, en naciones cristianas, se asumía que buena parte dela felicidad era de base espiritual y que por ello seríamos premiados. Hoy la felicidad es más material y asociada al cuerpo, "todos queremos ser más jóvenes y usted puede"; "todos queremos ser más ricos y usted puede", podrían ser los lemas ocultos de esos mensajes hacia el consumo. Uno puede entrar y pasear por los medios y descubrir tantos modos de ganar esa felicidad materialista, para "mantenerse bellos", pero los imaginarios cambian. Varios movimientos sociales están desafiando el valor del dinero y se abren opciones, no diría que hacia un neo-hipismo, pues son menos románticos, más bien movimientos de tipo pro-ecológicos como los slow food y derivados.

P.V. Nos interesa indagar en las vinculaciones entre los imaginarios urbanos y la o lo político. En una entrevista que le hizo María Elvira Ardila usted afirmaba que "en los imaginarios se estudian las subjetividades ciudadanas y las luchas por imponer deseos colectivos". ¿Podría explicar esta idea?

A.S.Estárelacionada conloquedijeantes. Imponer deseos colectivosesloque relaciono con estar por fuera del marketing; he comparado el arte público con los imaginarios. En elartepúblico el artistaintervieneuna comunidad, en algúnlugar: 
una escultura, una plaza, etc. parahacerla conscientedeunaformadedominación, para resaltar la pérdida de un valor, de un símbolo; como hizo un grafitero en La Plata, Argentina (foto 129), cuando le puso un tapabocas al fundador dela ciudad, aludiendo a la famosa frase que le dijo el rey de España a Chávez: “¿Por qué no te callas?”, en la XVII Cumbre Iberoamericana de Jefes de Estado, en 2007.

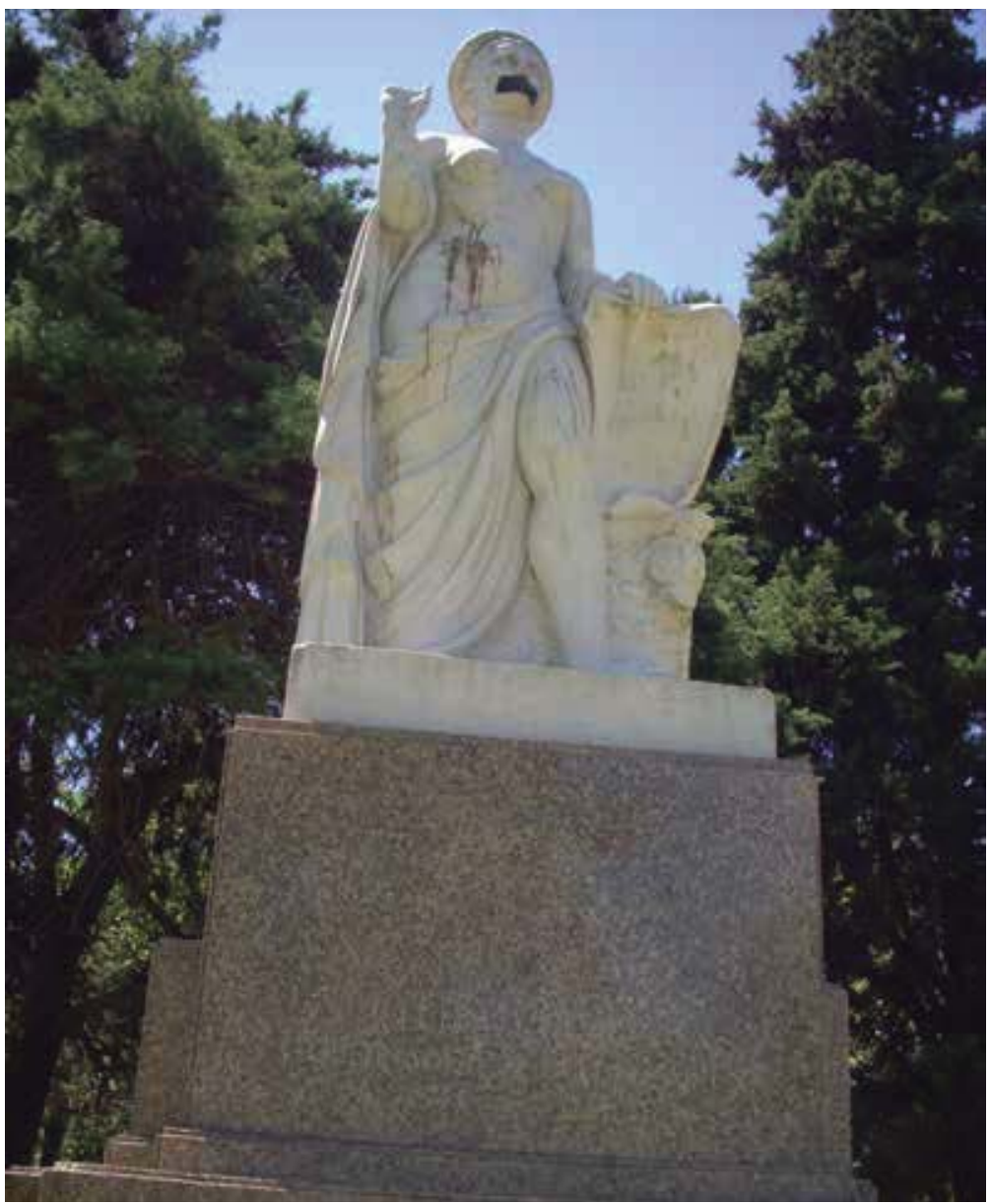

Enla Argentina delos Kirchner posiblemente quedará esta imagen (foto 13) de un artista público: una vaca que representa el orgullo nacional de "la mejor carne del mundo", asociada a nuevos nacionalismos, como lo indica la bandera que la rodea (¿derrotados?). Por analogía veo que, en su dimensión política, los ciudadanos pueden sacarse e imponer deseos de cambio en su entorno. 
Figura 13: La mejor carne del mundo, Argentina

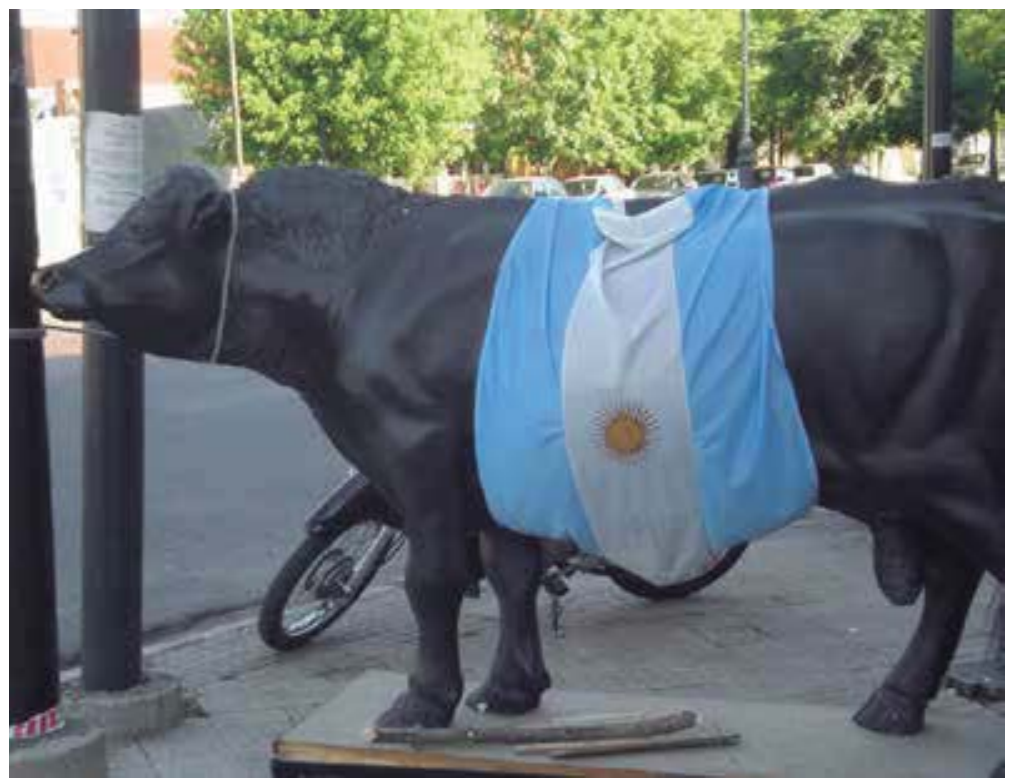

El uso de las redes es un buen ejemplo; el uso de la estética con fines de cambio hacia un buen vivir de la comunidad, otro. Como puede verse en una tesis sobre segregación en Quito norte/sur que usa nuestras categorías estéticosemióticas por parte del investigador Alfredo Santillán ${ }^{6}$.

La Venezuela de Maduro presenta cada día más el anhelo de sacarlo y las manifestaciones expresan ese deseo. Se ha dado un fenómeno interesante: Maduro y su gente atacan los medios foráneos (han sacado CNN y NTC 24 horas y muchos más), perola oposición usa sus celulares y cada ciudadano se convierte en reportero espontáneo y gratuito de esos medios internacionales para informar de la realidad silenciada por el actual gobierno que luego puede responder a esos "deseos ciudadanos" para evitar mala imagen internacional.

La señora Lilian Tintori, esposa del preso político Leopoldo López, denuncia el día 22 de abril de este 2017 que no dejan que ella ni sus hijos visiten a su esposo, y al otro día el defensor del pueblo la llama para decirle que ya puede visitarlo. Respondieron a los medios de afuera. El deseo de cambio es notable en la Venezuela de Maduro, no hay alimentos, por los medios se nos muestra a gente comiendo de los basureros y esto es una imagen muy poderosa que une la información externa con el silencio obligado interno; pero las inmensas marchas de abril y mayo de 2017 unen el clamor exterior con el interior.

6 En línea: http://revistas.javeriana.edu.co/index.php/cvyu/article/view/14682/12483 
En los micromundos pasa algo parecido, por ejemplo, como dije antes en las comunidades LGBTI. De hecho, mi novela que acaba de salir La mierda $y$ el amor trata el problema de las nuevas sexualidades, de cómo al estar encerrados en cuerpos de hombres o mujeres no se podía admitir algo distinto a este "destino natural". En el tráiler de Señorita María, la falta de la montaña ${ }^{7}$ se puede ver a una campesina atrapada en cuerpo de hombre, digo esto porque es una persona sencilla, sin ningún discurso teórico, simplemente no existía el imaginario transgénero, por eso no se veía su realidad y ella era invisible. Mi novela es la historia de un hombre que pierde su sexualidad masculina y cree que la solución es volverse mujer, pero descubre que no es lo uno ni lo otro, tampoco gay, a pesar de que sigue siendo un sujeto sexuado. En otro momento no se me escucharía, pero avanzamos en el arte y la literatura de hoy rompe viejas estructuras sociales. También los imaginarios urbanos se pueden anticipar a las leyes futuras, imponiendo nuevas realidades. La literatura y los medios ayudan a consolidarlos. A eso apunto con aquello de que algunos deseos colectivos se van emancipando.

P.V. En sus investigaciones usted trabaja ciertos desplazamientos tecnológicos: de la narrativa de la ciudad a la urbe de la web, de los álbumes de familia a las redes sociales, entre otros. ¿ Cómo han incidido las tecnologías digitales y el campo de sentidos que movilizan en la vida y la imaginación de las ciudades latinoamericanas?

A.S. Un texto póstumo de M. McLuhan sobre las leyes de los medios subraya que cuando un área de la experiencia se intensifica, otra queda bloqueada: el bolígrafo, por ejemplo, caduca la pluma de tinta. Cada tecnología llevada al límite de su potencial invierte sus características y se transforma en algo nuevo; la fotocopiadora, digamos, avanzó hasta hacer duplicados que superan (y eliminan, de hecho, su uso) el papel carbón, pero se revierte y "hace posible el plagio o la burla a los derechos de autor", como anota el argentino A. Piscitelli. A esto mismo se debe, seguramente, que cualquier tecnología, al recién "aparecer" llegue con visos de asombro y magia, como lo han demostrado quienes estudian el ambiente social existente cuando se inventó la radio, el teléfono, la fotografía, el cine, la televisión o Internet: sencillamente eran objetos increíbles y esta capacidad de asombro exalta su poder imaginario y demuestra la continuidad psicológica entre el pensamiento pre-científico y la tecnología moderna. La tecnología, en fin, sirve de gafas a los imaginarios urbanos. En América Latina, según cada país, hay un medio en especial que ha contribuido más a la construcción del imaginario nacional; por ejemplo: el cine en México, la TV en Brasil y la radio en Colombia.

Si nos detenemos en el desplazamiento de las nuevas tecnologías, sobresale que Trump está usando Twitter, desplazando los encuentros y asesores, para

7 En línea: https://www.facebook.com/PeliSrtaMaria/videos/887739294662755/ 
informar sobre sus acciones de gobierno e inclusive para dar a conocer el lanzamiento de bombas en Afganistán, con el notorio nombre, otro desplazamiento semántico, de "madre de todas las bombas"; lo que cambia de manera total el protocolo de mediación de otras instancias. Pero en otros lados la tecnología se usa en la vida cotidiana, desplazando otras acciones. El tráfico ya nolo maneja la policía, sino Waze: ubicamos el destino más rápido, pero perdemosla habilidad para encontrar nuestra propia vía.

Si hoy entramos en histeria cuando se cae la Web, con los días no podremos desconectarnos a costa de quedar por fuera del sistema. Los movimientos mundiales por el derecho a la desconexión chocan con otro derecho: el de estar conectados, aunque lo digital no quiere decir globalización. Las nuevas tecnologías son responsables de buena parte de la circulación de anhelos urbanos. Si uno mira con atención y deja afuera ruidos de escándalos o los archivos confidenciales o familiares, encuentra también imaginaciones ciudadanas hacia cambios que son de tener presente por su capacidad embrionaria.

P.V. Usted sostiene que los imaginarios son una teoría de la percepción social, ¿cómo se relaciona con la acción social?

A.S. En mi libro Imaginarios, el asombro social trato este tema y busco respuesta desdela lógica. El imaginario que concibo es de otro orden al puramente racional o psíquico; se trata de una manera de pensar y sentir al mismo tiempo: es una teoría de los sentimientos y de su expresión colectiva, manifestándose de modo grupal.

Para el filósofo y lógico Charles Peirce, el concepto es guía de la acción, está presente en la acción misma; es lo que le da sentido a la acción, la hace significativa. La acción como mera respuesta física se hace acción humana en el proceso de la semiosis. Peirce entiende el hábito como "ley de acción", por tanto concibe el pensamiento en sentido amplio, como lo que cubre toda nuestra vida racional; y se puede entender, analógicamente, "como acción mental". Así que mi colega, la profesora M. Restrepo, al pensar mi perspectiva de imaginarios con Peirce ve esta analogía que considero un aporte de su reflexión: el pensamiento genera creencia, la creencia desde la percepción produce hábitos, los hábitos conducen a la acción. Y concluye: la significación es lo que empuja a la acción. Pero mientras en Peirce el pensamiento mueve, en los imaginarios el deseo impulsa esos "propósitos comunes". Los "deseos humanos se orientan predominantemente hacia el porvenir" decía Freud, por tanto no necesariamente concuerdan con sus representaciones presentes y avanzarían, en palabras de hoy que agrego, a una producción imaginaria.

En rigor, en los imaginarios, más que ser la consecuencia de una episteme, avanzamos hacia una teoría de la percepción donde lo emotivo y sensorial, el recorrido de lo "deseante" marca una ruta entre psiquis y representación de una particular dimensión que lleva a actuar. Más que episteme sería su fusión 
con lo aisthetiko. Las certezas se desvanecen, el sujeto no se reduce al conocer (como proyecto positivo de la ciencia), se amplía la incertidumbre y se reorganiza - diría que estéticamente - la mirada ciudadana. Esto mismo ocasiona una fusión, y es la identificación del sujeto con su objeto. Digamos que el sujeto en estado imaginario está en su deseo.

P.V. Para finalizar, ¿cuál es la importancia de indagar imaginarios urbanos? ¿Cómo nos pueden ayudar los estudios sobre imaginarios urbanos a mejorar la vida en nuestras ciudades?

A.S. Bueno, ya he dicho bastante. Pero destaco que es una dimensión de lo subjetivo que ha desarrollado una metodología, la cual proviene no solo de las ciencias sociales, sino de la hermenéutica y del arte, por lo que aporta nuevas herramientas para acercarnos a nuevas realidades, donde lo subjetivo es determinante y "esta realidad de los deseos" no alcanza a leerse solo con las herramientas tradicionales.

Pongo como ejemplo el plebiscito en Colombia, en 2016, sobre la firma de paz con las FARC; donde todas, sin excepción, las encuestadoras fallaron al darle el triunfo al SÍ sobre el NO. En una columna de opinión en El Tiempo ${ }^{\mathbf{8}}$, y usando un criterio del arte contemporáneo, la incerteza, anuncié lo contrario: el triunfo del No. Luego abrí un debate en otra columna, "Verdad y emoción", y preguntaba a las empresas encuestadoras de opinión cómo es posible que hayan reconocido luego de su derrota que no les corresponde estudiar las emociones (lo dijeron en una mesa periodística). Entonces contesté: cómo no tener presente en el voto ciudadano las emociones de los colombianos frente a la FARC, quizá la institución más rechazada en este país, asociada a la violencia, a los secuestros, al narcotráfico, a violaciones y a los abortos obligados de sus compañeras. Por eso fallaron, porque aspectos de amplia subjetividad se desconocieron. Lo mismo pasó con el triunfo de Trump y el Brexit.

Vivimos momentos muy emocionales. La gente siente incierto el futuro.

8 En línea: http://www.eltiempo.com/opinion/columnistas/armando-silva/verdad-y-emocion-armando-silvacolumna-el-tiempo-54625 


\section{IDENTIFICACIÓN DEL ENTREVISTADO}

Armando Silva es PhD en Filosofía y Literatura Comparada de la Universidad de California; donde escribió, bajo la asesoría de Jacques Derrida, su tesis Family Photo Album; the imagen of ourselves, que fue ganadora del premio a la mejor tesis doctoral en las universidades de California en 1996. Es autor de Imaginarios urbanos (10 ediciones, traducido en varias lenguas) y 19 libros más. También es director del proyecto internacional "Imaginarios urbanos", editor de la serie "Ciudades imaginadas" y del programa audiovisual "Ciudades imaginadas para TV". Ha sido invitado a grandes eventos mundiales de arte y cultura, como Documenta 11 en Kassel, Alemania (2002), la Bienal de São Paulo (2004) y la Bienal de Venecia (2006). Su obra completa en retrospectiva se exhibió en la Fundación Antoni Tàpies de Barcelona, 2007. Es columnista de El Tiempo y Director del Doctorado en Estudios Sociales de la Universidad Externado de Colombia. En su primera novela (La mierday el amor, Bogotá, Taller Rocca, 2017) explora, desde la ficción, las nuevas sexualidades del siglo XXI. 